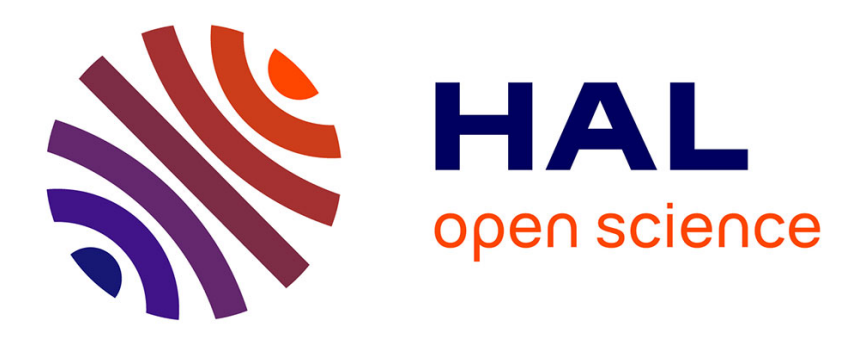

\title{
Yams as Vernacular Methodology? Approaching Vital Process through Technical Processes
}

Ludovic Coupaye

\section{To cite this version:}

Ludovic Coupaye. Yams as Vernacular Methodology? Approaching Vital Process through Technical Processes. Les actes de colloques du musée du quai Branly, 2016, 6, 10.4000/actesbranly.673 . hal03505699

\section{HAL Id: hal-03505699 \\ https://hal.science/hal-03505699}

Submitted on 31 Dec 2021

HAL is a multi-disciplinary open access archive for the deposit and dissemination of scientific research documents, whether they are published or not. The documents may come from teaching and research institutions in France or abroad, or from public or private research centers.
L'archive ouverte pluridisciplinaire HAL, est destinée au dépôt et à la diffusion de documents scientifiques de niveau recherche, publiés ou non, émanant des établissements d'enseignement et de recherche français ou étrangers, des laboratoires publics ou privés. 


\title{
Les actes de colloques en ligne du musée du quai Branly
}

Des êtres vivants et des artefacts

\section{Yams as Vernacular Methodology? Approaching Vital Process through Technical Processes}

\author{
Ludovic CoupaYe
}

\section{Résumé}

Cette présentation commencera par exposer quelques-uns des résultats obtenus lors d'une enquête sur des pratiques impliquant des « artefacts vivants », la culture et la présentation des grandes ignames décorées des Abelam de Papouasie-Nouvelle-Guinée. Puis on montrera quelques exemples des rapports entre processus vitaux et processus techniques tels qu'on peut les repérer à partir d'études portant sur les relations entre artefacts et êtres vivants dans quelques régions d'Océanie. Depuis le recours à des procédés techniques pour manifester la présence vivante d'entités ancestrales ou divines, jusqu'à la mobilisation d'entités vivantes dans la monstration de principes essentiels aux yeux des communautés humaines, on suggèrera que l'analyse des processus vitaux par les processus techniques peut mettre au jour des théories vernaculaires. 
As Perig Pitrou has recalled, this question of the relationship between life processes and technical processes started out of conversations that turned into work sessions in a UCL office.

2 His description of the Mixe ritual (Pitrou 2012, 2015) was for me an opportunity to think about the role of rituals in my own examination of gardening practices amongst the Abelam of Papua New Guinea. The bringing together of our interest for developing a conceptual frame enabling the exploration of Mixe's emic conception of life as it appeared through the making of ceremonial deposit mesas with my own investigation of the Nyamikum Abelam ceremonial display of decorated yams as processes-made things, led us to talk about a series of themes which are fundamental to Melanesian ethnography and to material culture studies in general. These themes evolved around the ways in which different cultures have thought about the relationship between people and things and, in a wider frame, humans and non-humans, and our discussions turned to the relationship between artefacts and living beings.

3 It appeared to us that the role taken by the "The One Who Makes Live" in the mesas ritual was not far from the ones taken by invisible entities in Nyamikum such as the waalë, water-spirits, or the Gwaal, powerful clan ancestors, both of which are called upon during specific moments of the cultivation processes. Our discussions of the sources of actual agencies of these entities in our respective rituals brought to light what would be called "productive misunderstandings". Treating yams as artefacts - and not as plants - was for me a way to first, contribute to discussions on the place of things in Melanesia, and second, to make a methodological experiment by applying a methodology so far restricted to material culture to a slightly different type of objects. Perig kept bringing me back to the question of the sources and types of agencies at work in the yam ritual (taking for granted that the entire cultivation process could be considered as a whole year-long ritual), while myself I was trying to find out the place of and the agencies attributed to "artefacts" (or things) in the Mixe's.

Those debates forced us to shift our respective analyses and seek an analytical common ground. This first took us towards the distinction that our analyses were making between "artefacts" and "living beings", and from there, we came to agree that such distinction could only exist in the light of the processes that were treating them as such. It appeared that in the course of our rituals, no ontologies were really permanent and that in one step, a thing (including an intangible one, such as an invisible power) could be considered a living being, for instance, imbued with certain agencies, while in another step, it could be just an inert thing. And vice versa. In other words, in was only by investigating the particular circumstances within the processes in their entirety that we could see, not only the sources of agencies at play, but also when specific entities could be considered as objects or subjects, as well as living beings or artefacts. The elements of our ritual invited us to think about ontologies as being fundamentally located within a specific cosmological frame but at times also transient. As a result, we had to shift towards the idea of processes, as an analytical category, allowing us then to highlights local conceptions of life and of techniques. Later on, discussions with Laura Rival, opened up our scope to think about the wider scale of ecology. Her focus on human-plants relations-to be fair, stronger than mine (Rival 2012), due to the long tradition of Americanist anthropology-brought a wealth of other theories to the fore, insisting on the fundamentally social nature of human relations to their ecosystem.

5 These discussions were evidently at an analytical level. Our interests were about unveiling indigenous models, but the comparative frame that our debate imposed was forcing us to refine our etic categories, be explicit about their validity and their limits. In the end, we agreed on thinking together about the ways in which technical processes and living processes, as analytical categories, were imbricated in 
indigenous experience.

\section{Technical Processes and Living Processes}

The relation between technical processes and vital processes is far from being a new concern, even from a Euro-American perspective. The case of the history of machines illustrates a conceptual proximity which was not reduced to a functional dimension, but which, from its inception, implied a specific conception of life (Brun 1985: 6). From war machines to theatre machines - the two main domains in which mechanics were applied from the Antiquity until the industrial era - both indeed were acting not on nature, but on life (Vaucanson's and Jacquet-Droz's automata, such as the Duck, or the Flute player, were exemplary). Whilst inscribed within an increasingly dominant mechanistic cosmology, and precluding the conceptual shift which made the machine as 'productive apparatus' a major trope in the nascent industrialisation of work processes, these machines were mostly made to demonstrate some properties of living beings (Bedini 1964).

7 From an anthropological perspective, these examples illustrate that the relations between technical processes and vital processes, be they distinct or merged, has always been localised within, and contingent to, a specific onto-cosmological frame, which allocates properties of living beings and artefacts. One of the best examples (in English) is perhaps Michael Rowlands and Jean-Pierre Warnier's paper on iron working in Cameroon Grassfields, in which they demonstrate that the relation between metallurgy and the reproduction of human beings is not based on a metaphorical analogy, but rather on the assumption that both belong to the same "natural" domain (1995).

8 But my question here is not so much to define the ontological regimes dominating the observed artefacts-living beings relations, but rather how to map out the complexity and the diversity of these particular relations. This is this very diversity, or rather heterogeneity, as presented in the colloquium, which offers a counternarrative to the dominant Euro-American paradigm of "technology" and challenges its direct application to our ethnography.

9 This challenge goes both ways. Towards contemporary experiments, such as Eduardo Kac, which brings back the artistic component into relation with bio-technology; also towards more classical ethnographies where modern machines increasingly play a role in "traditional" processes (such as sago processing in Indonesia, see Roy Ellen's presentation), or where production processes present characteristics which go far beyond a utilitarian or productivist interpretation, such as processes including magical or ritual activities (see Rupert Stasch 2016 and Perig Pitrou 2016).

10 Thus the mapping out of the imbrications of these two categories of processes, whose distinction might at time dissolve, or on the contrary remains in order either to intentionally produce "hybrids" or to separate entities considered as belonging to different domains, is a crucial step to visualise when and where continuities and discontinuities occur, and how these act. In doing so, it may allow us to delineate ethnotheories about our own categories of "life" and "techniques".

My presentation is about this particular methodological point: how to visualise these relations, and their heterogeneity and how to account for the different logics displayed by the actors, sometimes within the same process. My example will draw from my ethnography of yam cultivation in the village of Nyamikum, Maprik district, the East Sepik Province in Papua New Guinea. 


\section{Waapi: artefacts and living beings}

The Abulës-speakers of the Maprik district, known in the literature as the Abelam, have been made famous in anthropology and beyond for their visual production, associated with elaborate initiation ceremonies (Forge 1966, 1973; Hauser-Schäublin 1989; Smidt and McGuigan 1990), and the cultivation and annual display of richly decorated long yams (Dioscorea alata; waapi in Abulës; Lea 1964; Coupaye 2013). While initiations are no longer performed (in Nyamikum the last one was organised in 1964), long yam cultivation and annual displays are still an important part of Abelam contemporary life

13 Nyamikum village shares a boundary with the provincial district main town Maprik, in the southwest. The village is composed of about twenty to thirty hamlets, spread on the ridges of the foothills of the Prince Alexander Range, as well as in the main valley of the Mitpëm river. Like other Abulës-speaking, Nyamikum people are distributed throughout about twenty exogamous patrilocal clans. Up until a couple of decades, the ceremonial life was articulated by the division of the village between two moieties ( $a r a$ ), cross-cutting the clan division, and extending relations beyond the boundaries of the village.

Nyamikum people are gardeners, whose main activities evolve around swidden horticulture, while also cultivating sago-palm tree groves, and engaging in cash-crop cultivation (coffee, cocoa and, since 2002, vanilla). Two main species of yam are cultivated, D. esculenta and D. alata. While esculenta, the smaller yams, used for regular consumption are planted in generic gardens, whose access is open to all members of the household, long yams, by contrast, alata, destined for ceremonial use, are cultivated in gardens which are more secluded, away from main footpaths, and their access is officially restricted to male members of the community. Both gardens follow the general process of swidden horticulture (Conklin 1961): a small portion of the secondary forest is cut out and burned, then divided into several plots, each allocated to a gardener. Several species are intercropped, including several species and cultivars of yams, as well as of banana and taro, and a variety of greens. After three years of planting cycles, the plot is left to fallow until the secondary forest is regrown.

Long ceremonial yams waapi, once harvested, are decorated with the same materials and implements as those used before for human initiates, following a visual register analogous to the one used on carvings and paintings. Adorned waapi are then displayed during a specific ceremony, called in Nyamikum, Waapi Saaki - "the lining up of long yams." Once the ceremony finished, long yams become exchanges items.

The role of the waapi is fourfold: as food to be consumed; as valuable to be exchanged; as images to be displayed; and as plant to be cultivated. It is this multivalence which gives long yams their enduring pervasiveness in Abelam social relations. But it also invites us to think about how Abulës-speakers imbue these "artefacts" with such capacities. Such a centrality makes waapi the centre of Abelam concerns and metaphors, including during public meetings and discourses. At the moment of their display, their appearance places them somewhere (and such ontological uncertainty, upon which their very power rests, might well be intentional) between images of ancestors, indexes of human capacity for (re)productivity, and vegetal cosmological beings which, though inherently transient, have the botanical capacity to grow underground and then re-emerge and re-appear every year in a new guise, whilst containing the same power.

It is the origin, or rather the making of such capacities which was at the subject of my original investigation. Whilst Melanesia is replete with examples in which people and things (such as shells valuables, ornaments, netbags or mats and in some case pigs) are substitute of one another and where yams too-and their cultivation-are at 
the centre of elaborated ritualistic practices (Malinowski 1935), cases where tubers are decorated and displayed in ways that makes their relation to ancestral powers visible are less widespread.

My aim was to delineate how yams were made powerful, and in the course of the investigation it gave some possible clues about why yams were considered as appropriate for such role. The answers, unsurprisingly, lie between their nature as vegetal living beings of a specific kind and the processes of their cultivation.

\section{The Chaîne Opératoire as a graphic device}

It is not necessary to remind a French audience of the work of an entire generation of ethnographers (such as Robert Cresswell, Hélène Balfet, Marie-Claude Mahias or Pierre Lemonnier; cf. Bartholeyns et al. 2011) who have investigated techniques in a huge diversity of contexts. Suffice to say that their work has demonstrated in a definitive way the inherently social nature of ways of making and doing, by focussing primarily on actions on materials, following the path opened by André LeroiGourhan (1936), in the tradition of Marcel Mauss, and resorting to the methodological tool of the chaîne opératoire.

I have detailed elsewhere the sequence of operations of Nyamikum yam cultivation between 2002-2003, starting from the selection of the plot and ending with the replanting of the tuber (Coupaye 2009, 2010, 2013). In this presentation, I will only insist on some ethnographic elements of the sequence which illustrate a particular imbrication of technical and living processes. It can also be noticed that this particular methodology only allowed me to "follow of the yam" throughout Nyamikum life. Whilst this did not result in a full ethnographic account of the Abelam, nor even of Nyamikum village per se, it allowed me to generate what could be described as an "ethnographic account of yams in Nyamikum", a sort of "transect" of Nyamikum social life - a sociality which included people, as well as materials, invisible entities, materials and substances (Coupaye 2015, see fig. 1).

Figure 1 (from presentation).

\section{"Following the making of the yams"}

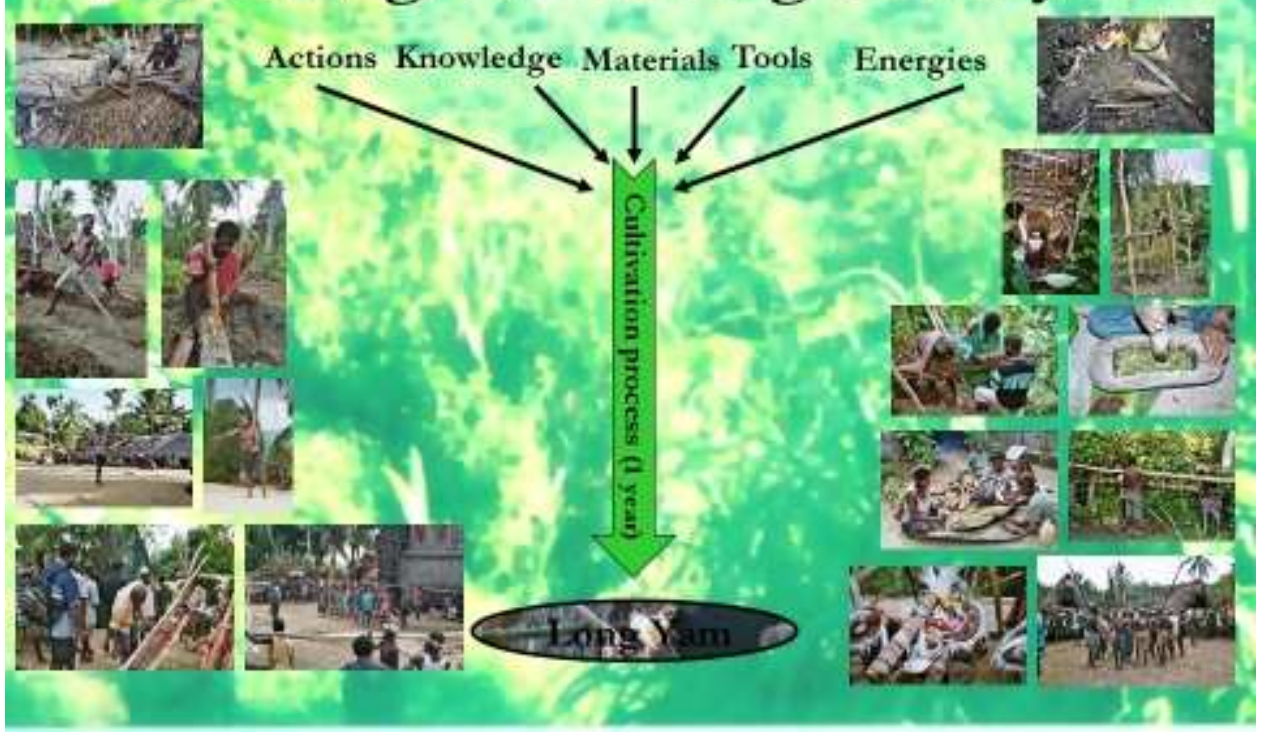

Following the cultivation process took me through different aspects of Nyamikum social life, usually treated 
from the angle of kinship, gender, religion, politics, environments, art, etc. The "components" of the chaîne opératoire are based on Lemonnier's etic descriptors (1992). In the reality of the field, these components are often put to question and at time need to be suspended (see discussion in Coupaye 2013: 159-206)

As I synthesised in figure 1, in following of the entire sequence of making long yams, several aspects of Nyamikum social life unfolded: from gardening practices, of course, as well as kinship, rituals, public debates, inter-village relations, understanding of vegetal and animal species, impact of modern practices of cash-crop, political debates during the pre-national election campaign (Coupaye 2007).

This idea of "transect", inspired from a method used in ecology, to sample out species existing in ecosystems such as a forest or a field, corresponds to a chronological description of the sequence of operations and actions, through the different places they occur. This corresponds to following the making of a particular artefact, and recording the different contexts, concepts, "components" recruited in the process, as long as they were recognised by actors themselves as required or necessary. Such a description (whose linearity is only temporal, as it follows the actual sequence of actions and events), as in ecology, offers the possibility to graphically give an image of the process and to outline, at any given moment, the relation between the different components of the "technical systems" (Gille 1986 [1978]; Lemonnier 1992; Coupaye 2013, 2015).

Figure 2. The chaîne opératoire as a transect through collectives, follows the sequences of actions ("efficacious" and "traditional" according to the actor) through several collectives.

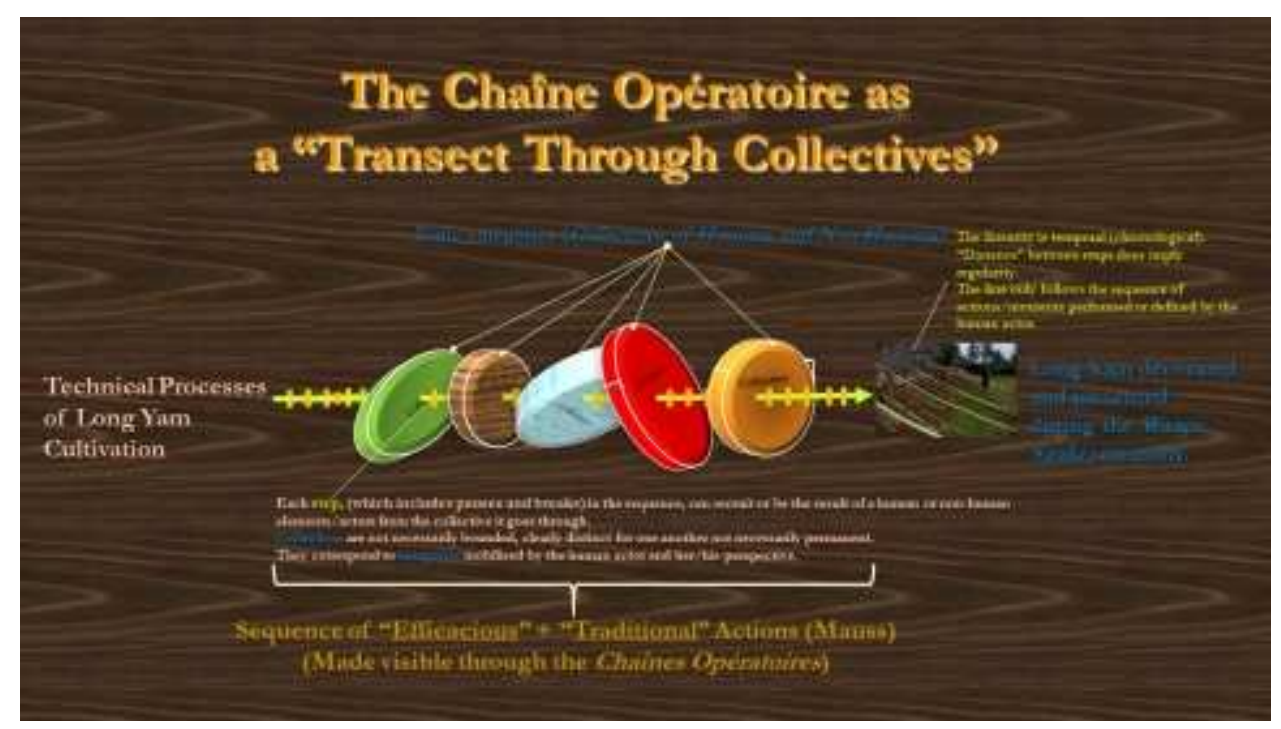

Steps can involve different agencies, not all stemming from the human actors. Collectives can be transient, or intersect one another (See Coupaye 2013: 159-206)

\section{The making of yams (partial account)}

As indicated, I have described in more details the cycle elsewhere (Coupaye 2013), and will only focus on a couple of aspects of the process, in order to highlight some cases in which investigating the imbrication of technical processes and living processes revealed specific local understandings of what yams are, what cultivation does, and what is part of it.

First, I will start with a presentation of the "general model" of cultivation, well known from researchers working on swidden horticulture (inspired by Conklin 196; see also Coupaye 2013: 94-95) as a chaîne opératoire (See fig. 3). 
Figure 3. General model of shift cultivation. Steps are simplified (e.g. Opening includes: selection of the part of the secondary forest; cutting down the vegetation; drying of the remains; burning; cleaning).

\section{Operational Sequence of Gardening (shifting cultivation, rainforest)}

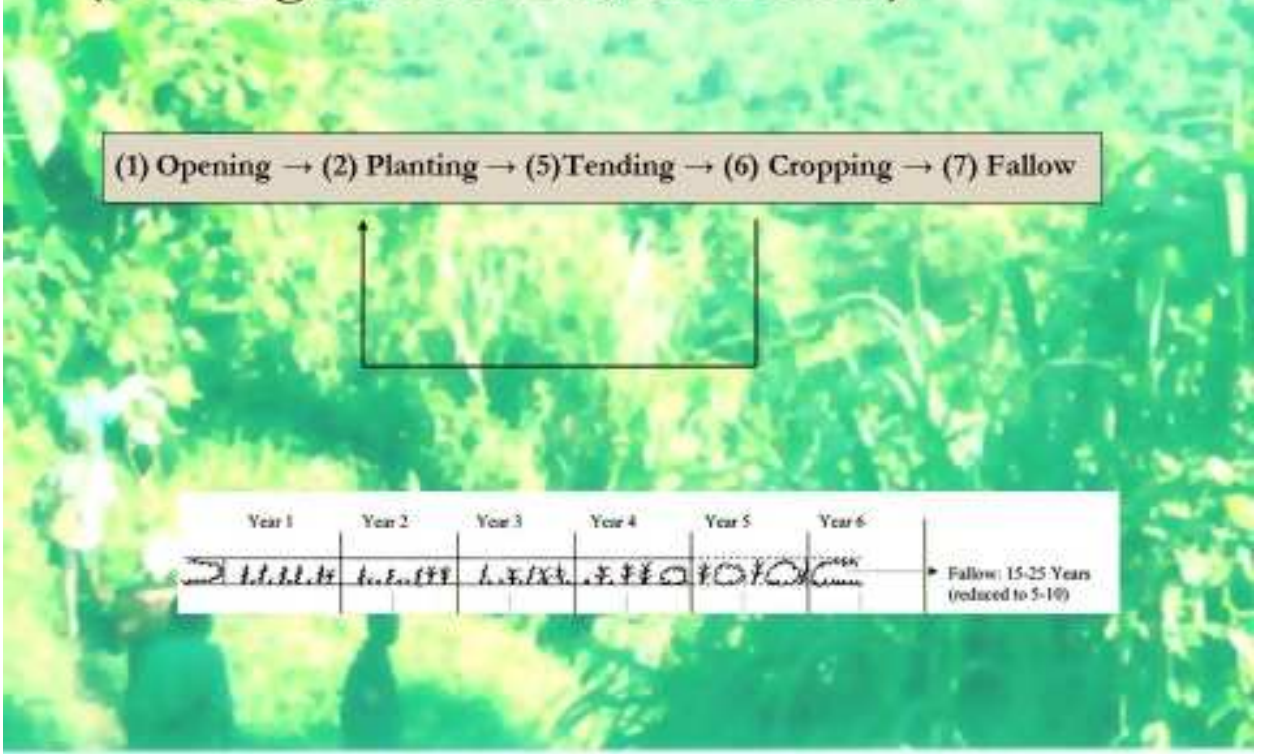

After the harvest (cropping), the plot is re-planted with a slightly different set of species. Below: This replanting, each one different from the previous year's one, can be repeated for a total of 4 years (usually 3 ), each time indicating a different name for the garden, identified by a specific term (see Coupaye 2013: 94)

Depending on whether we follow the human actor or the garden plot, our understanding of the process can be different. In the upper part of fig. 3, it is interesting to note here the recursive dimension of the cycle, not so much in terms of full circle, but rather as a helicoidal flow, never really coming back to its exact point of departure. Indeed the crops replanted in the second rounds do not come from the same stock as the ones in the previous cycle: as a matter of fact, crops harvested in the old garden are replanted in the new one, and the one harvested in the latter are always planted in a newly opened garden. As for the lower part of fig. 3, it tells a different story, one that sees the succession of vegetation each year in the same space.

In the following section, I will scale up the process to show only a few characteristics emerging from our investigation of the imbrication between technical processes and living processes, as they appear in the chaîne opératoire. These are the inherent sequentiality of the process - that is a definite (appropriate) order of operations -, the efficacy of rituals as technical/living processes in themselves, and the agentive properties of non-human beings and the type of living processes they demonstrate.

\section{Sequentiality}

People familiar with the Technologie Culturelle will recognise in the sequences above the subtle ballet of "internal logics" and "strategic tasks" (Balfet 1975: 52; Lemonnier 1992: 21-24), which impose a particular order in the sequence for the entire project to be "effective" and to succeed. However, resorting to Mauss's (1973 [1935]) understanding of "efficacy" as conceived by the actors, allows us to introduce indigenous logics, not so much in terms of determinisms, but more in terms of emic reasons for actions. 
For instance, before the forest is cut down, be it for a long or a short yam garden, cultivators and their wives start the set of behavioural and food prescriptions and proscriptions, called the Yakët. This set of taboos is said to prepare the body and cleanse it from a range of nefarious substances (see Coupaye 2013: 165-172), the main one being menstrual blood, kalebany. The menstrual blood accumulates in the female body and is seen as transmitted to her male partner through regular contact, mostly through sexual intercourse. The menstrual blood is said to be particularly inimical to people's Jëwaai, a crucial body quality and substance (not entirely dissimilar to the Polynesian mana), which resides in people's blood, scent and sweat. The Jëwaai affects the result of many enterprises involving the human body (such as gardening, but also magic, gambling or even a football game).

As the cultivator cuts the vegetation down to open a new garden, his sweat falls on the ground. There, not only the land itself (see Huber-Greub 1988), but also giant ancestral earthworms, named baëkwaam, can smell the gardener's Jëwaai and can prevent illegitimate users of the land, or people having breached their Yakët, to grow food successfully.

This process displays two important points regarding the question of vital processes and technical processes. First, it testifies a continuity between vital processes in humans and in plants. Second, as shown in figure 4, the Yakët, according to Nyamikum people, is thus a required and essential step in the process, to be necessarily conducted before any garden work, and which occupies in their conception an analogous role to Pierre Lemonnier's definition of "strategic tasks", which, if not performed at a specific moment, jeopardise the success of the entire process.

\section{Figure 4. The Yakët, set of "taboos", is a step necessarily occurring before any work in} the garden, as it affects the gardener's body and its substances (Jëwaai).

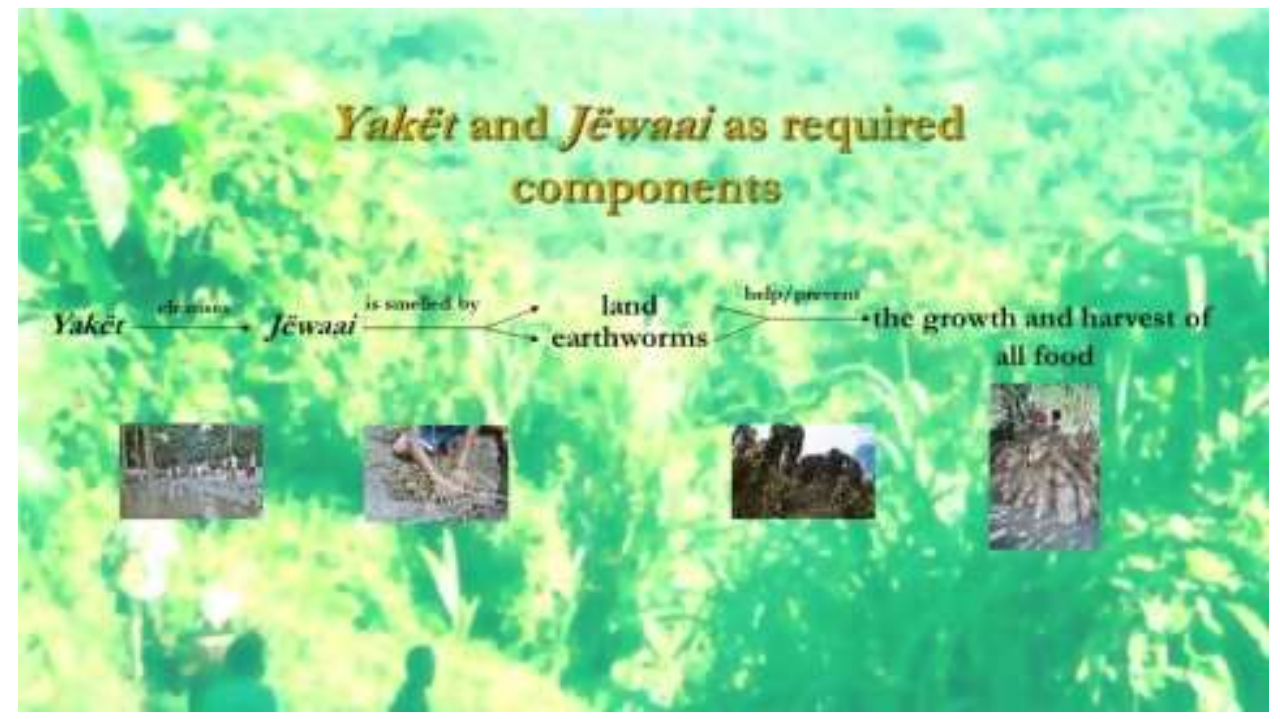

These substance penetrates the ground, through the sweat and is smelled by non-human agents, who have the capacity to control the growth of plants

The Yakët in itself corresponds to a particular technique or discipline of the self, aimed at materially transforming the person's body and at creating the prerequisite physical state to ensure that (technical) actions are performed in an efficacious and successful way. These techniques include the whipping of the body with stinging nettles, to make the blood "hot"; the avoidance of salt, sugar and water to make the body "dry" or the stabbing of the glans with a razor blade to get rid of the kalebany; some people, put off by the pain of the latter practice, prefer go to the Maprik hospital and donate blood, though this is scorned by older generations.

For the ethnographer of techniques, not only does it reveal an emic understanding of "efficacy", of "action" or of "material", but it also provides the local explanation for the sequence in itself. It also implies a conception of life made of the circulation and 
combination of substances within and across bodies, a theme often highlighted in Melanesian ethnography (e.g. Bonnemère 1996; Strathern 1999).

\section{Ritual efficacy}

Several rituals occur in the course of the cycle, some at a very small scale performed by individuals, while others, collective, can mobilise the hamlet. These are not seen in isolation from the cultivation process in itself, in particular, for the older generation, who often insist on these as the most important step (see Coupaye 2009: 104; 2013: 110-112; 117-118). They often complain about the lack of steadfastness in the younger generation's observance of the Yakët, and attribute most contemporary social troubles in the village to the abandonment of kastom (Tok Pisin for "custom"). The cleansing of the hamlets, Gaay nëbël), in particular, is a step which collectively performs the same type of purification as the Yakët does for people's bodies. It ensures that negative influences coming from conflicts and polluting people's Jëwaai are removed, creating a sense of communal cooperation towards the harvest of food.

Yet, it is the Waapi Saaki, the long yam ceremony, marking the official end the cycle, which is indicated as being central in the entire process. Ganbakiya, a very successful long yam grower, synthesises it by saying (originally in Tok Pisin) that

the WaapiSaaki is meant to celebrate and please the long yam waapi, so that they will come back the following year. And as waapi open the road to all food that comes out of the garden, if you don't harvest waapi, you will die of hunger.

This explanation does more that solely justifying the role of the ceremony. Indeed, the intensity and complexity of interactions, songs, dances, praises by visitors from other villages of the exhibited decorated tubers (Coupaye 2013: 207-228), all is seen as contributing to the growth of the yams which will be planted on the next cycle. This, in particular shows the role that the ethnographer has to give to local reasons, rather than investigating determining causes (fig. 5), and demonstrates that social relations in themselves are seen as a necessary component to the growth of the tubers.

Figure 5. The contribution of the ceremony to the food production.

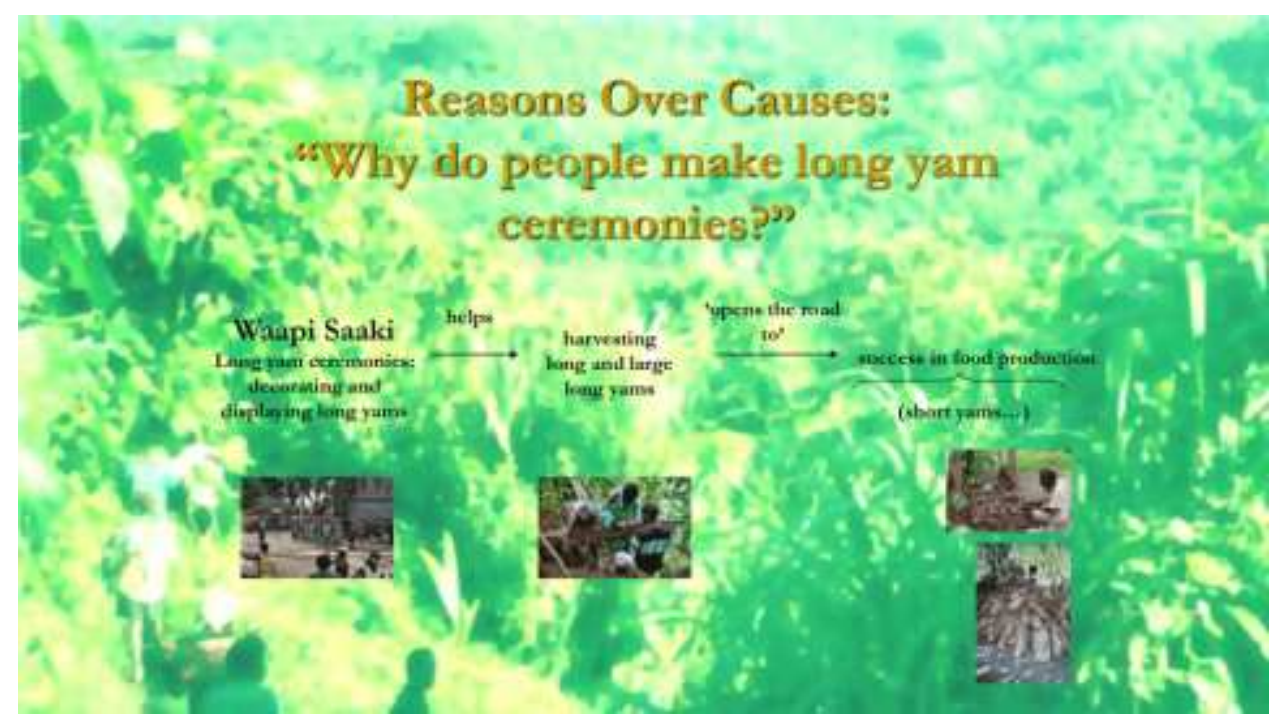

The title of the slide refers to the role anthropologists can attribute to the analyses of the reasons given by actors, rather than finding external causes

This also points towards two properties, one about the overall "technical process" of yam cultivation, and the second, about the "living processes" animating yams. Not only is the ceremony itself thought to be inseparable from other "technical" activities (such as digging the ground to plant the tuber, or staking the yam vines), but in 
people's narratives, yams appear as living sentient beings, receptive to the sociality manifested during the Waapi Saaki.

\section{Yams as living beings}

It might not be surprising that in these narratives, yams themselves appear not only as living beings, but also as sentient ones, capable of their own intentional agency.

Indeed, indigenous taxonomy used for their description seems to associate them more with the animal domain than with the plant one. Their bodies have hands (the vines), but also a head (the corm), a tail (the terminal end of the tuber) as well as hair (the small rootlets on the tuber itself) and teeth (the terminal root system). Most of them have particular functions: the vines reach out and catch the sun and the rain, the hair protects them and the roots chew the ground.

This terminology could be attributed to the fundamental metaphorical nature of Abulës language, in particular in public speeches, which use an identified form called Aaja Kudi (the "Veiled Speech"), which relies heavily on set of analogies, synecdoches and other tropes, meant to reveal (and conceal) important properties of the existing world (Huber-Greub 1988: 255-266; Coupaye 2013: 194-197). Yet, yams are rarely, if ever, metaphors themselves. Rather, other phenomena are used to talk about yams in these public speeches, such as the return of specific birds (notably the Hornbill, Paal), but also football matches (referring to the competitive exchanges of waapi between teams of ceremonial partners) or even national elections (Coupaye 2007).

Less than discourses in themselves, the sets of practices and behaviour surrounding interactions with the plants in the course of their cultivation pertains to our present concerns. What these behaviours seem to indicate is that yams have a capacity to sense, evaluate and react (see Coupaye 2013: 44-46). For instance, one should never enter a garden, be it a short yam or a long yam one, and start working immediately; this would disturb the tranquillity of all the plants (the yams, mainly). Rather, one should first go quietly to the garden shelter, build a fire, roll and smoke a cigarette and chew an areca nut, before any other form of interaction, in order to give the plants the time to get accustomed to the presence of the cultivator(s).

Similarly, behaviours in the garden are supposed to be quiet and respectful. Not only should humans never step over a plant or a vine lying on the ground, but because yams react to noise and effervescence - as we've seen during the WaapiSaaki - voices should never be raised. The same capacity to react to sounds is at the source of the efficacy of magical songs, manëgup, performed often when alone, sotto voce while blowing gently on the vines to help them grow. On a different topic, while sexual intercourse is the main Yakët proscription, while hiding in the long yam garden shelter with close friends, talking and giggling about sex is said to please the yams.

Yams are said to possess not only a form of auditory sense but also an olfactory one. Smelling food, and specific substances placed in the ground as part of "magic", is said to help them to grow faster. Their skin also reacts to the administration of itchy substances, made of specific vine sap, exciting them and making them grow faster and deeper into the ground.

But contradictory accounts can also occur, revealing less the trickery of language than the ability of gardeners to provide accounts that leave rooms for interpretations. Thus, the same Ganbakiya, considered in many respects one of the masters of yam magic, humorously pointed out to me that yams couldn't hear because "they have no ears".

While in the previous snapshots, I have concentrated on modalities of actions, 
here, I am rather pointing out type of "life-qualities" attributed to non-humans. The same type of sentience and agency can also be attributed to other garden species, or indeed other types of beings.

\section{Human \& Non-Human Agencies}

The following of the cultivation process reveals the central role of human agencies, not only in terms of physical actions - such as the staking and building of the trellises for the tuber vines, or the digging of the ground in order to create a berth of softened soil to favour the development and growth of the tuber underground - but also the fundamental role of sociality and relations between partners and kin.

However this sociality also include relations with a range of "non-human agents", be it to enrol their participation, assure their benevolence, or avoid their nuisance. One of the most important ones is perhaps the secret stone, held in a secluded shrine in specific hamlets, which acts, as the gardeners themselves describe, as a "power station" for all the village gardens. The stone is the depository of the "heat" of social relations, gathered during public meeting, stored in the shrine, and then redistributed throughout all the village (and sometimes beyond) through the installation set in the shrine. The shrine decorations and items (coconut shells, shellrings, feather ornaments) deposited next to the stone activate iconical and indexical relations, opening channels for the stone fertility to circulate on a grid that innerves the whole territory.

But the stone does not act alone. Gwaaldu, the clan ancestral beings are called upon in silent spell-songs and their individual names are invoked and sometimes given to exceptional tubers, confirming the power contained in names. Another set of powerful, yet dangerous, entities, the waale, living in water-holes of their clan territory, appear as the embodiment of a clan capacity to grow food, and can make the rain fall and destroy the elaborate trellises. Also invoked in song-spells, the waalë also provide water for the making of magical substances administered to the tuber. As for the baëkwaam, as we mentioned, these giants multi-coloured earthworms, that one can sometimes hear "mooing" at night, act as actual agents of the stone, able to smell the Jëwaai, evaluate the behaviour of a gardener, report to the stone, and attack the tuber if its owner has breached his Yakët or even if he is using illegitimately the land of another clan. Other entities, such as the Christian God or butterflies resting on the vines, also contribute the development of the plants.

The role of these collectives appears mostly through the enactments of specific techniques. The role of the body, and obviously the hand, appears as the main vector for contact. For instance, staking and laying the yam vines on the trellises during the period when the vegetation grows quickly, are very delicate operations, operated by touch and movements which have to be gentle to avoid the breaking the fragile growing vine; during this operation, the breath also plays its role, blowing gently or singing while touching the plant, and naming ancestral beings in order to gain their approval or their contribution.

Non-human agents are thus contributing to and infusing technical processes with agencies, conditions and substances, confirming, if necessary, that "techniques", "materials" and "actions" are socialisation enacted.

\section{Conclusion: Displaying vernacular models}

It is clear that the binaries of "living being"/“artefact", "life processes"/"technical 
processes" are but heuristic categories whose separation can only be used to build what Perig calls a cadran analytique, an analytical framework constructed to map out the heterogeneity of the two phenomena we are investigating (Pitrou 2016).

But the ultimate aim to unveil and analyse ethnotheories does more than document yet another set of examples of emic logics - a goal that can be buried under philosophical discussions within anthropology. Bringing together and crosscutting our concerns has also enabled comparison of the ways in which anthropological discussions have engaged with concepts of life and of techniques, as well as of their relationships. In other words, this two-fold approach, helps us pointing out how people think about life, about techniques and about these two domains, whose imbrications have always been there, but which Modernist paradigms have often obscured.

Resorting to a "general pragmatics" (Pitrou 2015) is thus a way to pay attention to the logics displayed by people's actions, their heterogeneity, and the interpretations they present us with, be they explicit, through orality, or implicit as the cultivation of yams hopefully makes apparent. Laura Rival's discussion of the manioc civilisation, and her careful description of the kari makushi is yet another example, if necessary, of how the imbrication of technical processes and life processes keeps unearthing indigenous logical necessities.

Not only does this imbrication correspond to indigenous conceptions of plant cultivation, but it also forces us to rethink our understanding of plants and ecosystems as being distinct from technical systems. But it does so without necessarily inviting us to analytically reduce both terms to the point at which the underlying etic nature of our interpretative models obviates the very paradigms from which they emerge. This is a common sense statement, but the rigorous application of this keeps bringing forth novel interpretations of landscapes and organisms that live in them (see for instance Rival \& McKey 2008 ; McKey 2016).

If anything, the main difference with the investigation on the agency of "The One Who Makes Live" and its relation to Mixe's conception of "life" is that, instead, I have followed yams and the multiple agencies that have contributed to give them their central place in Nyamikum imagination.

And this brings me to my last suggestion, one about indigenous "imagination". At one point of their trajectory, yams have the capacity to be images constructed to be displayed. But as I suggested elsewhere (Coupaye 2013: 264-290), what is "given to see" during the Waapi Saaki is precisely this: the requirement of multiple agencies and of the imbrication of heterogeneous processes for a successful reproduction of life. If I am correct, this could well correspond to a Nyamikum "general pragmatics", that is "the basis of a global system of actions and agents" (Pitrou 2015: 2), given shape in the form of a decorated tuber, and then displayed to all. In doing so, perhaps, Abulës-speakers present to themselves - and to us - with a vernacular methodology to understand conjointly what are, according to them, the imbrications between "technical processes" and "life processes".

\section{Acknowledgments}

I wish to thank the Fondation Fyssen, the Départment de la Recherche et de l'Enseignement of the musée du quai Branly, and the Mairie de Paris for the support given to the colloquium. I am also immensely grateful for the discussions and debates engaged between 2012 and 2013 between Perig Pitrou and myself, first, then with Laura Rival, without which a number of ideas would not have emerged. Thanks to Alexandra Fanghanel for her careful edition. The data presented in this paper have been collected during a 17 months fieldwork in Nyamikum village, of the Maprik District, in the East Sepik Province of Papua New Guinea, in 2001-2003 funded by 
the Robert Sainsbury Scholarship. An additional trip in June-July 2014 was made after the colloquium, allowing me to verify some interpretations and gather some new material, some of which have been integrated in the written version of this oral presentation. I am thus immensely grateful to the cultivators who spent time with me and gave me access to their knowledge and opinions about yam cultivations, and all ethnographic mistakes are mine, and mine only.

\section{Bibliographie}

Bartholeyns, Gil, Nicolas Govoroff \& Frédéric Joulian (éds.)

2010 « Cultures matérielles : anthologie raisonnée de 'Techniques \& Culture' «, Techniques \& Culture, 54-55.

Bedini, Sylvio

1964 " The role of automata in the history of technology ", Technology and Culture 5 (1): 24-42.

Bonnemère, Pascale

1996 Le pandanus rouge : corps, différence des sexes et parenté chez les Ankave-Anga. Paris, CNRS Édition, Éditions de la Maison des Sciences de l'Homme.

Brun, Jean

1985 « Biographie de la machine », Les Études Philosophiques 1 : 3-16.

Coupaye, Ludovic

2007 "Beyond mediation: the long yams of Papua New Guinea », in Celina Jeffery and Gregory Minissale(éds.), Global and local mediations: (in)between art histories. Cambridge, Cambridge Scholar Press: 205-230.

2009 "What's the matter with technology? Long (and short) yams, materialisation and technology in Nyamikum village, Maprik district, Papua New Guinea ", The Australian Journal of Anthropology 20: 93-111.

2010 « Décrire les objets hybrides », Techniques \& Culture 52-53 : 50-67.

2012 « Des images, des nœuds et des toiles », Techniques \& Culture 58 : 142-159.

2013 Growing artefacts, displaying relationships: yams, art and technology amongst the Nyamikum Abelam of Papua New Guinea. Oxford \& New York, Berghahn Books.

2015 « Chaîne opératoire, transects et théories : quelques réflexions et suggestions sur le parcours d'une méthode classique ", in Philippe Soulier (éd.), André Leroi-Gourhan " l'homme tout simplement ». Paris, Éditions de Boccard, Travaux de la Maison de l'Archéologie et de l'Ethnologie René-Ginouvès : 69-84.

Cresswell, Robert

2010 [1976] " Techniques et Culture : Les bases d'un programme de travail », in Gil Bartholeyns et al., Cultures matérielles : anthologie raisonnée de "Techniques \& Culture ».Techniques \& Culture 54-55: 20-45.

Descola, Philippe

2013 [2005] Beyond nature and culture. Chicago, Chicago University Press.

Forge, Anthony

1965 " Art and environment in the Sepik ». Proceedings of the Royal Anthropological Institute for 1965: 23-31.

Forge, Anthony

1973 "Style and meaning in Sepik art », in Anthony Forge (éd.), Primitive art and society. London \& Oxford, Oxford University Press, Ely House: 169-92.

1990 "The Power of Culture and the Culture of Power », in Nancy Lutkehaus, Christian. Kaufmann, William E. Mitchell, Douglas Newton, Lisa Osmundsen and Meinhard Schuster (éds.), Sepik Heritage. Durham, Carolina Academic Press: 160-70.

Gille, Bertrand

1986 [1978] The history of techniques. New York, Gordon and Breach Science Publishers.

Haudricourt, André-Georges

1987 [1962] " Domestication des animaux, culture des plantes et traitement d'autrui », in André-Georges Haudricourt (éd.), La technologie, science humaine : recherches d'ethnologie et d'histoire des techniques. Paris, Maison des Sciences de l'Homme : 277-285.

1987 [1964] « Nature culture dans la civilisation de l'igname : l'origine des clones et des clans ", in André-Georges Haudricourt (éd.), La Technologie, science humaine : recherches d'ethnologie et d'histoire des techniques. Paris, Éditions de la Maison des Sciences de 
l'Homme : 287-98.

Hauser-Schäublin, Brigitta

1989 Kulthäuser in Nordneuguinea. vol. 1 :Architektur, Funktion und Symbolik des Kulthauses bei den Abelam ; vol. 2 :Vergleichende Studien zu Kulthaüsern im Sepik-Gebiet und an der Nordküste. Abhandlungen und Berichte des Staatlichen Museums für Volkerkunde Dresden. Berlin, Akademie-Verlag.

Huber-Greub, Barbara

1988 Kokospalmenmenschen : Boden und Alltag und ihre Bedeutung im Selbstverständnis der Abelam von Kimbangwa (East Sepik Province, Papua New Guinea). Basler Beiträger zur Ethnologie, Band 27. Basel, Weipf \& Co. AG Verlag.

Lea, David A. M.

1964 Abelam land and sustenance horticulture in an area of high population density, Maprik, New Guinea. Thèse de doctorat soutenue à l'Australian National University, Canberra.

Lemonnier, Pierre

1976 « La description des chaînes opératoires : contribution à l'analyse des systèmes techniques », Techniques et culture 1 : 100-150.

1992 Elements for an anthropology of technology. Ann Arbor, University of Michigan Press.

2012 Mundane objects: materiality and non-verbal communication. Walnut Creek, Left Coast Press.

Leroi-Gourhan, André

1936 "L'homme et la nature », in Lucien Febvre (éd.), Encyclopédie Française, Tome VII : L'Espèce humaine (dir. Paul Rivet): 10 (3)-12(4).

Malinowski, Bronislaw

1978 [1935] Coral gardens and their magic: a study of the methods of tilling the soil and of agricultural rites in the Trobriand Islands. New York, Dover Publication.

Mauss, Marcel

1979 [1935] " Body techniques ", Part IV inSociology and psychology: essays by Marcel Mauss (traduits par B. Brewster). London, Routledge and Kegan Paul: 95-123.

McKey, Doyle

2016 " Do farmers use, and imitate, self-organizing resource-concentration mechanisms driven by non-human engineers in constraining environments? Biocultural landscapes and biomimicry at the ecosystem level », in Perig Pitrou, Ludovic Coupaye et Fabien Provost (éds.), Actes du colloque "Des êtres vivants et des artefacts : l'imbrication des processus vitaux et des processus techniques ", 9 et 10 avril 2014, musée du quai Branly, Paris. [http://actesbranly.revues.org/667].

Pitrou, Perig

2012 " Figuration des processus vitaux et co-activité dans la Sierra Mixe de Oaxaca (Mexique) », L'Homme 202 : 77-111.

2014 « La vie, un objet pour l'anthropologie ? Options méthodologiques et problèmes épistémologiques », L’Homme $212: 159-189$.

2015 « Life as a process of making in the Mixe Highlands (Oaxaca, Mexico): towards a 'general pragmatics' of life », Journal of the Royal Anthropological Institute 21 (1): 86-105.

2016 « Êtres vivants/artefacts, processus vitaux/processus techniques : remarques à propos d'un cadran analytique ", in Perig Pitrou, Ludovic Coupaye et Fabien Provost (éds.), Actes du colloque "Des êtres vivants et des artefacts : l'imbrication des processus vitaux et des processus techniques », 9 et 10 avril 2014, musée du quai Branly, Paris. [http://actesbranly.revues.org/653].

Rival, Laura

2012 " Animism and the meaning of life: towards an understanding of manioc domestication », in Marc Brightman, Vanessa Elisa Grotti \& Olga Utlurgasheva (éds.), Animism in rainforest and tundra: personhood, animals, plants and things in contemporary Amazonia and Siberia. Oxford \& New York, Berghahn Books: 69-81.

Rowlands, Michael \& Jean-Pierre Warnier

1995 " The magical production of iron in the Cameroon Grassfield », in Thrustan Shaw et al. (éds.), The archaeology of Africa: food, metals and towns. London, Routledge, One World Archaeology, 20: 512-50.

Schlanger, Nathan

2005 " The chaîne opératoire », in Colin Renfrew and Paul Bahn (éds.), Archaeology: the Key Concepts. London \& New York, Routledge : 25-31.

Sigaut, François

2003 « La formule de Mauss », Techniques \& Culture 40 : 153-168.

Smidt, Dirk \& Noel D. McGuigan 
1994 " An emic and etic role for Abelam art (Papua New Guinea): the context of a collecting trip on behalf of the Rijksmuseum voor Volkenkunde, Leiden », in Philip C. Dark and Roger Rose, Artistic heritage in a changing Pacific. Honolulu, University of Hawaii Press: 121-41.

Stasch, Rupert

"The iconicity and indexicality of 'life' in Korowai Sago grub feasts », in Perig Pitrou, Ludovic Coupaye et Fabien Provost (éds.), Actes du colloque "Des êtres vivants et des artefacts: l'imbrication des processus vitaux et des processus techniques », 9 et 10 avril 2014, musée du quai Branly, Paris. [http://actesbranly.revues.org/669].

Strathern, Marilyn

1999 Property, substance and effect: anthropological essays on persons and things. London \& New Brunswick, The Athlone Press.

\section{Pour citer cet article}

Référence électronique

Ludovic Coupaye, "Yams as Vernacular Methodology? Approaching Vital Process through Technical Processes », in Des êtres vivants et des artefacts, Paris («Les actes »), 2016, [En ligne], mis en ligne le 20 janvier 2016, Consulté le 08 février 2016. URL :

http://actesbranly.revues.org/673

\section{Auteur}

\section{Ludovic Coupaye}

Ludovic Coupaye est Lecturer au Département d'anthropologie d'University College London, où il a rejoint la section Material Culture Studies. Ses travaux entrecroisent l'anthropologie de l'art, des techniques et de la culture matérielle aussi bien francophone qu'anglophone. Son terrain de recherche privilégié est en Papouasie Nouvelle-Guinée. II enseigne l'anthropologie et l'histoire des arts d'Océanie à l'Ecole du Louvre, et est l'un des coordinateurs du GRDI «Anthropologie et Histoire des Arts » du département de la recherche du musée du quai Branly, et du séminaire « Culture Matérielle » au même endroit. II est notamment l'auteur de Growing artefacts, displaying relationships: yams, art and technology amongst the Nyamikum Abelam of Papua New Guinea (Berghahn Books, 2013).

[l.coupaye [@] ucl.ac.uk]

\section{Droits d'auteur}

(C) Tous droits réservés 